Supporting Information

\title{
Interleukin-17A Peptide Aptamers with an Unexpected Binding Moiety Selected by cDNA Display under Heterogenous Conditions
}

Hiroki Anzai, ${ }^{\dagger}$ Takuya Terai, ${ }^{\dagger,,^{*}}$ Kanako Wakabayashi-Nakao, ${ }^{\ddagger}$ Taro Noguchi, Shigefumi Kumachi, ${ }^{\ddagger}$ Masayuki Tsuchiya, ${ }^{\ddagger}$ and Naoto Nemoto ${ }^{\dagger,}$,**

${ }^{\dagger}$ Graduate School of Science and Engineering, Saitama University, 225 Shimo-Okubo, Sakura-ku, Saitama City, Saitama 338-8570, Japan.

${ }^{\ddagger}$ Epsilon Molecular Engineering, Inc., 255 Shimo-Okubo, Sakura-ku, Saitama City, Saitama 338-8570, Japan.

" (Present address) Department of Chemistry, Graduate School of Science, The University of Tokyo, 7-3-1 Hongo, Bunkyo-ku, Tokyo, 113-0033, Japan.

*E-mail: terai@chem.s.u-tokyo.ac.jp (T.T.); nemoto@fms.saitama-u.ac.jp (N.N.). 


\section{Materials and Methods}

\section{Materials and general instruments}

General chemicals were of the best grade available, supplied by Tokyo Chemical Industries (Japan) and Wako Pure Chemical Industries (Japan). Chemicals for molecular biology experiments were obtained from SIGMA and Wako Pure Chemical Industries. They were used without further purification. Serum (from equine or human (pool)) were obtained from Cosmo Bio (Japan). Peptides were synthesized by standard Fmoc solidphase peptide synthesis using Prelude X synthesizer (Gyros Protein Technologies, U.S.A.) except HAP, which was synthesized by Scrum Inc. (Japan). DNA oligos were obtained from Eurofins Genomics and Tsukuba Oligo Service (Japan). PCR were performed with a Biometra TRIO48 thermal cycler (Analytik Jena, Germany). qPCR was performed with a StepOne system (Applied Biosystems, U.S.A.), using THUNDERBIRD SYBR qPCR Mix (Toyobo, Japan). Unless otherwise stated, PrimeSTAR HS DNA polymerase (Takara, Japan) was used for PCR under the conditions recommended by the manufacturer, and DNA was purified by FavorPrep PCR Clean-Up Mini Kit (Favorgen Biotech, Taiwan). Ethanol precipitation was performed with Quick-Precip Plus Solution (Edge BioSystems, U.S.A.). RNA was purified by RNAClean XP (Beckman Courter, U.S.A.). Gel images were taken with a Typhoon FLA9500 imager (GE Healthcare, U.S.A.). Unless otherwise stated, PAGE analysis of DNA and RNA were performed at $60{ }^{\circ} \mathrm{C}$ using gels containing $8 \mathrm{M}$ urea, with $0.5 \times$ TBE as a running buffer. SDS-PAGE analysis of cDNA display molecules and peptide-linker complexes were performed at r.t. using Tris- $\mathrm{HCl}$ gels containing $8 \mathrm{M}$ urea. Next generation sequencing was performed with a MiSeq sequencer (Illumina, U.S.A.). Biolayer interferometry was performed using a BLItz system (ForteBio, U.S.A.). Surface plasmon resonance (SPR) measurement was performed using Biacore T200 (GE Healthcare, U.S.A.). Absorbance measurement of ELISA was performed using Infinite M Plex (TECAN, U.S.A.). For cDNA display formation, a puromycin linker described in our previous literature (CNVK-rG linker)S1 was used.

\section{Serum stability test of a model cDNA display library}

A DNA library encoding a random peptide (Figure S1), which had been prepared in our laboratory for a different selection, was used as a model. First, the DNA was transcribed to mRNA using T7 RiboMAX Large Scale RNA Production System (Promega) and photoligated to the cnvK-rG linker. The obtained mRNA-linker complex was then translated in vitro with a rabbit reticulocyte lysate system (Promega, 6 pmol of mRNA-linker was 
added in a $50 \mu \mathrm{L}$ reaction volume) at $30{ }^{\circ} \mathrm{C}$ for $20 \mathrm{~min}$. After incubation in the presence of high $\mathrm{K}^{+}$and $\mathrm{Mg}^{2+}$ to promote mRNA display formation, the mRNA display library was immobilized on streptavidin (SA)-coated magnetic beads (Dynabeads MyOne Streptavidin $\mathrm{C} 1$ magnetic beads, Invitrogen, U.S.A., $60 \mu \mathrm{L}$ ) at $25{ }^{\circ} \mathrm{C}$ for $30 \mathrm{~min}$. The immobilized library was then reverse-transcribed by the ReverTra Ace reverse transcriptase (Toyobo, Japan, $200 \mathrm{U}$ in a $50 \mu \mathrm{L}$ reaction volume) at $42{ }^{\circ} \mathrm{C}$ for $30 \mathrm{~min}$. RNase T1 (250 U in $50 \mu \mathrm{L}$, Thermo Fisher Scientific, U.S.A.) was added to the beads, and the mixture was incubated for $15 \mathrm{~min}$ at $37^{\circ} \mathrm{C}$ to release the mRNA/cDNA-protein fusion molecules (i.e., cDNA display) from the beads. The eluted crude cDNA display library was purified by the His6 tag inserted at the C-terminus of the protein, using His Mag Sepharose Ni beads (20 $\mu \mathrm{L}$, GE Healthcare, U.S.A.). The purified cDNA display and mRNA-linker were independently incubated with equine serum (final concentration was $1 \%$ in PBS-T) at $25{ }^{\circ} \mathrm{C}$ for $120 \mathrm{~min}$, and then the cDNA display only was treated with RNase H (New England Biolabs, U.S.A.) at $37^{\circ} \mathrm{C}$ for $30 \mathrm{~min}$. The serum was prepared from commercially available equine defibrinated blood (Cosmo Bio, Japan) by centrifugation at $1000 \times \mathrm{g}$ for $15 \mathrm{~min}$. The collected samples were analyzed by SDS-PAGE (4\% stacking- $6 \%$ separating, $20 \mathrm{~mA}, 120 \mathrm{~min}$ ) containing $8 \mathrm{M}$ urea, and visualized by fluorescence of the ${ }^{\mathrm{n} v \mathrm{~K}-\mathrm{rG} \text { linker. }}$

\section{DNA library construction}

The DNA library used for in vitro selection of human IL-17A was prepared by 2-step primer-overlap extension PCR from the primers shown in Table S5. First, DNA coding $(\mathrm{NNK})_{11}$ was extended using DNA polymerase (10 cycles, $0.4 \mathrm{~mL}$ scale) with C11Random and His cnvK-NewYtag as primers. The obtained double strand product was purified by preparative PAGE (6\%, denaturing condition). Second, overlap extension PCR to attach 5'-UTR was performed ( 12 cycles, $0.4 \mathrm{~mL}$ scale) with above DNA and T7PURE as primers. The product was purified by preparative PAGE (6\%, denaturing condition), and the final PCR amplification was performed for 5 cycles with Newleft and cnvK-NewYtag as primers. The sequence of the final product was checked by Sanger sequencing.

\section{Preparation of cDNA display coding randomized cyclic peptides}

Transcription of DNA library was performed with a T7 RiboMAX Large Scale RNA Production System (Promega, U.S.A.) according to the manufacturer's instruction, and mRNA was purified. mRNA $(1 \mu \mathrm{M})$ was then hybridized to ${ }^{\mathrm{cnv}} \mathrm{K}-\mathrm{rG}$ linker $(1 \mu \mathrm{M}) \mathrm{s} 1$ at the 3 '-terminal region in $25 \mathrm{mM}$ Tris- $\mathrm{HCl}$ ( $\mathrm{pH}$ 7.5) with $100 \mathrm{mM} \mathrm{NaCl}$ under the following annealing conditions: heating at $90{ }^{\circ} \mathrm{C}$ for $1 \mathrm{~min}$ followed by lowering the temperature 
to $70{ }^{\circ} \mathrm{C}$ at a rate of $0.4{ }^{\circ} \mathrm{C} / \mathrm{s}$, incubating for $1 \mathrm{~min}$, then cooling to $25{ }^{\circ} \mathrm{C}$ at a rate of $0.08{ }^{\circ} \mathrm{C} / \mathrm{s}$. The sample was irradiated with UV light at $365 \mathrm{~nm}$ using a CL-1000 UV Crosslinker (UVP, Upland, U.S.A.) for $30 \mathrm{~s}$. The obtained mRNA-linker complex was then translated in vitro with a PURE system (GeneFrontier, Japan, 12 pmol of mRNA-linker was added in a $50 \mu \mathrm{L}$ reaction volume) at $37{ }^{\circ} \mathrm{C}$ for $30 \mathrm{~min}$. To synthesize an mRNA-linker-protein fusion (i.e., mRNA display), $\mathrm{KCl}$ and $\mathrm{MgCl}_{2}$ were added to the mixture (final concentrations were $900 \mathrm{mM}$ and $75 \mathrm{mM}$, respectively), and the mixture was incubated at $37^{\circ} \mathrm{C}$ for $60 \mathrm{~min}$. After EDTA (final concentration was $70 \mathrm{mM}$ ) and an equal volume of $2 \times \mathrm{SA}$ binding buffer (20 mM Tris-HCl, pH 8.0, 2 mM EDTA, $2 \mathrm{M} \mathrm{NaCl}$, $0.2 \%$ Tween 20 ) was added, the mRNA display library was immobilized on streptavidin (SA)-coated magnetic beads (Dynabeads MyOne streptavidin C1 streptavidin magnetic beads, Invitrogen, U.S.A., $120 \mu \mathrm{L}$ ) at $25{ }^{\circ} \mathrm{C}$ for $30 \mathrm{~min}$. The beads were washed three times with $1 \times$ SA binding buffer $(100 \mu \mathrm{L}, 10 \mathrm{mM}$ Tris-HCl, pH 8.0, $1 \mathrm{mM}$ EDTA, $1 \mathrm{M}$ $\mathrm{NaCl}, 0.1 \%$ Tween 20). The immobilized library was then reverse transcribed by ReverTra Ace reverse transcriptase (Toyobo, Japan, $200 \mathrm{U}$ in a $50 \mu \mathrm{L}$ reaction volume) at $42{ }^{\circ} \mathrm{C}$ for $30 \mathrm{~min}$. After the beads were washed with $20 \mathrm{mM} \mathrm{NH}_{4} \mathrm{HCO}_{3}$, the immobilized cDNA display library on the beads was cyclized with cyclization buffer $(50 \mu \mathrm{L}, 20 \mathrm{mM}$ $\mathrm{NH}_{4} \mathrm{HCO}_{3}, \quad 5 \quad \mathrm{mM}$ tris $(2$-carboxyethyl)phosphine $\quad$ (TCEP), $\quad 2 \quad \mathrm{mM} \quad 1, \quad 2$ bis(bromomethyl)benzene, $10 \%$ acetonitrile, $\mathrm{pH} 7.4$ ) at $30^{\circ} \mathrm{C}$ for $30 \mathrm{~min}$. The beads were washed with His tag binding buffer $(100 \mu \mathrm{L}, 20 \mathrm{mM}$ sodium phosphate buffer, $0.5 \mathrm{M}$ $\mathrm{NaCl}, 5 \mathrm{mM}$ imidazole, $\mathrm{pH}$ 7.4), and RNase T1 (Thermo Fisher Scientific, U.S.A.) was added ( $250 \mathrm{U}$ in $50 \mu \mathrm{L}$ of His tag binding buffer) to the beads. The mixture was incubated for $15 \mathrm{~min}$ at $37^{\circ} \mathrm{C}$ to release the $\mathrm{mRNA} / \mathrm{cDNA}$-peptide fusion molecules (i.e., cDNA display) from the beads. Supernatant containing cDNA display molecules was purified using His6 peptide tag. Specifically, the above supernatant was added to His Mag Sepharose Ni beads (20 $\mu \mathrm{L}$, GE Healthcare, U.S.A.) and incubation was performed at $4{ }^{\circ} \mathrm{C}$ for overnight. The beads were washed with His tag wash buffer $(100 \mu \mathrm{L}, 20 \mathrm{mM}$ sodium phosphate buffer, $0.5 \mathrm{M} \mathrm{NaCl}, 20 \mathrm{mM}$ imidazole, $\mathrm{pH}$ 7.4), and incubated in His tag elution buffer $(20 \mu \mathrm{L}, 20 \mathrm{mM}$ sodium phosphate buffer, $0.5 \mathrm{M} \mathrm{NaCl}, 10 \mathrm{mM}$ EDTA, $0.05 \%$ Tween $20, \mathrm{pH} 7.4)$ at $25^{\circ} \mathrm{C}$ for $15 \mathrm{~min}$. The eluted fraction was used for in vitro selection.

\section{Confirmation of cDNA display formation (Figure S4)}

cDNA display library was prepared from 6 pmol of mRNA-linker complex as described above. Aliquots of mRNA-linker, input (= mRNA display) and supernatant of SA-bead immobilization, elution of RNase T1 treatment (= crude cDNA display), supernatant of 
His Mag Sepharose Ni beads, the collected his tag elution, and finally the buffer exchanged cDNA display (= buffer exchange, buffer was exchanged to PBS-T using Micro Bio-Spin 6 column, Biorad, U.S.A.) were taken and analyzed by SDS-PAGE (4\% stacking6\% separating, $20 \mathrm{~mA}, 120 \mathrm{~min}$ ) containing $8 \mathrm{M}$ urea. All samples corresponded to 0.5 pmol of library molecules, assuming that every step proceeded with perfect yield. The gel was fluorescently visualized with an FITC filter set, and band intensity was calculated to estimate the cDNA display formation efficiency. Regarding the last four samples, RNase H (Takara, Japan, $10 \mathrm{U})$ and 10× NE buffer 2 (1/10 volume, New England Biolabs, U.S.A.) was added to the samples and the mixture was incubated at $37^{\circ} \mathrm{C}$ for 30 min before loading to a gel to digest the RNA/cDNA duplex.

\section{Screening of human IL-17A using cDNA display system}

In brief, cDNA display of the first round selection was prepared using mRNA-linker complex (120 pmol) in the same method as above. The mRNA library for the first round was prepared by transcription of $1.3 \mathrm{pmol}\left(7.8 \times 10^{11}\right.$ molecules $)$ of the original DNA library. The resulting peptide library was applied to magnetic beads (Dynabeads MyOne Carboxylic acid, Invitrogen, U.S.A.) that had been conjugated with recombinant human IL-17A (obtained from Pepro Tech, U.S.A.)-immobilized using NHS activated ester reaction, and incubated at $25{ }^{\circ} \mathrm{C}$ for $60 \mathrm{~min}$. After the supernatant was removed, the beads were washed 3 times with $100 \mu \mathrm{L}$ of PBS-T (500 mM NaCl, $8.1 \mathrm{mM} \mathrm{Na}_{2} \mathrm{HPO}_{4}, 2.7$ $\mathrm{mM} \mathrm{KCl}, 1.5 \mathrm{mM} \mathrm{KH}_{2} \mathrm{PO}_{4}, 0.05 \%$ Tween 20, pH 7.4). Denatured eluate buffer (PBS-T containing 1\% SDS and $50 \mathrm{mM}$ 1,4-dithiothreitol (DTT), $100 \mu \mathrm{L}$ ) was added to the beads and incubation was performed at $50{ }^{\circ} \mathrm{C}$ for $30 \mathrm{~min}$. The collected cDNA display was purified, and then amplified for PCR using T7PURE and cnvK-NewYtag as primers. The amplified DNA was purified and uesd for the next round of selection. For the 2nd-5th rounds of selection, smaller-scale ( $24 \mathrm{pmol}$ in $2 \mathrm{nd}, 12 \mathrm{pmol}$ in $3 \mathrm{rd}, 6 \mathrm{pmol}$ in 4 th, $3 \mathrm{pmol}$ in 5th) mRNA-linker complexes were used. From the 3rd round of selection, the biotinylated human IL-17A was immobilized to streptavidin (SA)-coated magnetic beads (Dynabeads MyOne Streptavidin C1, Invitrogen, U.S.A.). After incubation with cDNA display library, elution of binding molecules with TCEP buffer (PBS-T, 10 mM TCEP, pH 7.4) was performed at $25{ }^{\circ} \mathrm{C}$ for $15 \mathrm{~min}$. The biotinylation of human IL-17A was performed using EZ-Link Sulfo-NHS-SS-Biotin (Thermo Fisher, U.S.A.) under the conditions recommended by the manufacturer, and the biotinylated human IL-17A was immobilized to SA-coated magnetic beads at $25^{\circ} \mathrm{C}$ for $60 \mathrm{~min}$. Additionaly, the incubation of cDNA display library and IL-17A-immobilized beads was performed in the presence 
and absence of serum (PBS-T containing 1\% serum of equine in the 3rd round, PBS-T containing $10 \%$ serum in the 4 th round, and PBS-T containing $10 \%$ fresh serum from mice in the 5th round, respectively). Serum from mice was a kind gift from Drs. Sakata and Sakai (Saitama University).

\section{Next generation sequencing}

Initial and final DNA library of the selection were analyzed by deep sequencing with MiSeq (Illumina). Preparation of DNA samples for sequencing was performed according to the manufacturer's instruction. Obtained DNA sequences were converted to peptide sequences, and sorted in terms of read numbers. Top 100 sequences of each selection (i.e., with/without serum) were analysed.

\section{Logo plots}

Illumina next generation sequencing data from the 5th round was used to construct logo plots using WebLogo (http://weblogo.berkeley.edu/logo.cgi) for 13 mer sequences (11 mer of randomised amino acids and two flanking Cys) present at a level of 100 different peptides.

\section{Construction of DNA constructs encoding identified peptides}

The DNA constructs were prepared by 2 -step primer-overlap extension PCR. The first extension was performed using a reverse primer coding the peptide of interest (such as IL17-1 in Table S5) and T7PURE as the forward primer. Second PCR was then performed with obtained DNA as a template and Newleft and His cnvK-NewYtag as primers. When necessary, purification using gel dissection was performed. The DNA constructs were

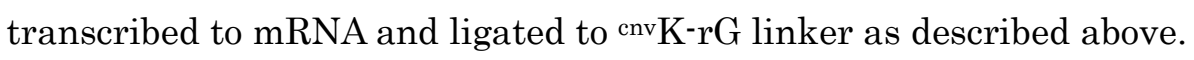

\section{Pull-down assay}

An mRNA-linker (12 pmol) coding the peptide of interest was converted to mRNA display as described above. After immobilization of mRNA display molecules on Dynabeads MyOne streptavidin $\mathrm{C} 1$ beads $(120 \mu \mathrm{L})$ at $25^{\circ} \mathrm{C}$ for $30 \mathrm{~min}$, the beads were washed with $20 \mathrm{mM} \mathrm{NH}_{4} \mathrm{HCO}_{3}(200 \mu \mathrm{L} \times 3)$. Then, the immobilized mRNA display on the beads was cyclized with cyclization buffer $(50 \mu \mathrm{L})$ at $30^{\circ} \mathrm{C}$ for $30 \mathrm{~min}$. The beads were then washed with His tag binding buffer $(100 \mu \mathrm{L})$, and RNase T1 was added (200 U in $50 \mu \mathrm{L}$ of His tag binding buffer) to the beads. The mixture was incubated for $15 \min 37^{\circ} \mathrm{C}$ to release the mRNA-peptide fusion molecules (i.e., peptide-linker) from the beads. Supernatant containing peptide-linker molecules was purified by His Mag Sepharose Ni beads $(20 \mu \mathrm{L})$ 
as described above. The obtained peptide-linker complex (= input, IP) was added with the human IL-17A-immobilized beads in PBS-T at $25^{\circ} \mathrm{C}$ for $60 \mathrm{~min}$. In the case of binding analysis using serum, the peptide-linker was incubated with $50 \%$ human serum/PBS-T at $37^{\circ} \mathrm{C}$ for $3 \mathrm{~h}$, and then the supernatant was added with IL-17A-immobilized beads at $25^{\circ} \mathrm{C}$ for $60 \mathrm{~min}$. Flow through $(=\mathrm{FT})$ was collected, and then the beads were washed twice with PBS-T (=wash). Finally, the bound peptide-linker was eluted with TCEP buffer at $25^{\circ} \mathrm{C}$ for $15 \mathrm{~min}$ (=elute 1, or just EL) and sometimes with denatured eluate buffer at $85{ }^{\circ} \mathrm{C}$ for $5 \mathrm{~min}$ (=elute 2). For the control, the intact Dynabeads MyOne streptavidin $\mathrm{C} 1$ beads were used, and the same protocol was implemented. The collected samples were analyzed by SDS-PAGE.

\section{Biolayer interferometry}

For the preparation of mRNA-linker, the same protocol was used as described above, except that the specialized puromycin linker called BLItz linker was used herein (5'BAAAAATFTCCAKGCCGCCCCCCGTCCTCCP-3', B: 5'-Biotin-TEG, K: cnvK, P: 3'Puromycin, F: FITC-dT). The mRNA-linker encoding peptide of interest ( 8 pmol) was converted to mRNA display as described above, and then RNase T1 (200 U) was added. The mixture was incubated at $37{ }^{\circ} \mathrm{C}$ for $15 \mathrm{~min}$. Next, $4 \times$ His tag binding buffer was added, and the peptide-linker was purified by His Mag Sepharose Ni beads. The purified peptide-linker was cyclized with cyclization buffer at $30{ }^{\circ} \mathrm{C}$ for $30 \mathrm{~min}$, and biolayer interferometry measurement using the peptide-linker was performed. A BLItz system was utilized for the affinity assay according to the manufacture's instruction. The above peptide-linker was used as a ligand and was immobilized on a biosensor tip coated with streptavidin. Recombinant human IL-17A, recombinant mouse IL-17A, or recombinant human IL-17F (Pepro Tech, U.S.A.) was used as an analyte.

\section{Stability test of selected peptides in human serum}

The peptide-linker was prepared from CNVK-rG linker as described above. The purified peptide-linker was incubated with human serum (final concentration was $50 \%$ in PBST) at $37^{\circ} \mathrm{C}$ for $24 \mathrm{~h}$. The collected samples were analyzed by SDS-PAGE ( $6 \%$ stacking$15 \%$ separating, $20 \mathrm{~mA}, 120 \mathrm{~min}$ ) containing $8 \mathrm{M}$ urea. Band intensities were quantified using the fluorescence of fluorescein, which was labeled at the puromycin linker. Decomposition percentage was calculated as follows.

Decomposition $(\%)=($ remaining peptide-linker after 50\% serum incubation / peptidelinker with buffer in input) $\times 100$ 


\section{Alanine scanning}

The DNA constructs encoding the peptide where each amino acid was replaced with alanine were prepared by extension PCR, and the peptide-linker was prepared using CNVK-rG linker as described above. The affinity assay was performed with a BLItz system as described before.

\section{Peptide synthesis}

\section{General Procedure for the Synthesis of Linear Peptide.}

Peptide-chain elongation was performed on H-Rink Amide ChemMatrix ${ }^{\circledR}$ resin or FmocNH-SAL resin using an automatic peptide synthesizer (Prelude X (Gyros Protein Technologies) or Alstra(Biotage)) by Fmoc-based solid-phase peptide synthesis. For the side-chain protection, $t$-Bu ester for Asp and Glu; Pbf for Arg; $t$-Bu for Thr, Ser and Thy; Boc for Lys and Trp; and Trt for Gln, Asn, His and Cys were employed. Fmoc-protected amino acids were coupled by using HCTU activation or HATU activation. Fmocprotecting group was removed by treatment with $20 \%$ piperidine in DMF. The resulting protected peptide resin was treated with a TFA cocktail [TFA/ $\mathrm{H}_{2} \mathrm{O} /$ triisopropylsilane/1,2ethanedithiol (94:2.5:1:2.5)] for $2 \mathrm{~h}$. After the removal of the resin by filtration, the filtrate was poured into ice-cold dry $\mathrm{Et}_{2} \mathrm{O}$. The resulting powder was collected by centrifugation and washed three times with ice-cold dry $\mathrm{Et}_{2} \mathrm{O}$.

Peptide 1. After the synthesis of protected peptides consisting of the sequence of peptide 1 (GSCELLTFLGYPVYCGGGSHHHHHH), coupling of 5-carboxyfluorescein (3 equiv) was carried out with DIC (3 equiv) /HOBt (3 equiv) activation in DMF. The resulting protected peptide was cleaved from resin, deprotected, and collected by the identical procedure described for the general procedure. The obtained peptide was purified by reverse phase (RP)-HPLC on a $\mathrm{C} 18$ semi-preparative column. The purified peptide containing a pair of cysteine was cyclized through disulfide bond by $10 \%$ DMSO in 10 $\mathrm{mM}$ Tris-HCl buffer containing of $\mathrm{MeCN}$ ( $\mathrm{pH}$ 8) overnight. The cyclized peptide was purified by RP-HPLC to provide peptide 1. MS (MALDI-TOF) calc for $\mathrm{C}_{143} \mathrm{H}_{178} \mathrm{~N}_{38} \mathrm{O}_{38} \mathrm{~S}_{2}$ $[\mathrm{M}+\mathrm{H}]^{+}: 3100.27$ Found 3100.27.

Peptide 2. Peptide 2 was synthesized by Scrum Inc (Tokyo, Japan).

Peptide 3. By the identical procedure described for the synthesis of peptide 1, labeling of the linear peptide with 5-carboxyfluorescein and cyclization of the labelled linear peptide were performed to provide peptide 3. MS (MALDI-TOF) Calcd for $\mathrm{C}_{95} \mathrm{H}_{117} \mathrm{~N}_{15} \mathrm{O}_{25} \mathrm{~S}_{2}$ 
$[\mathrm{M}+\mathrm{H}]^{+}: 1932.77$ Found: 1932.74

Peptide 4. After the synthesis of protected peptides consisting of the sequence of peptide 4 (MGSGGSCELLTFLGYPVYCSKG), acetyl capping was carried out with $\mathrm{Ac}_{2} \mathrm{O}$ (10 equiv) and pyridine (10 equiv) in DMF. The resulting protected peptide was cleaved from the resin, deprotected, and collected by the identical procedure described for the general procedure. The obtained peptide was purified by RP-HPLC on a C18 semi-preparative column. The purified peptide containing a pair of cysteine was cyclized through disulfide bond by $10 \%$ DMSO in $10 \mathrm{mM}$ Tris- $\mathrm{HCl}$ buffer containing of $\mathrm{MeCN}(\mathrm{pH}$ 8) overnight. The cyclized peptide was purified by RP-HPLC. The purified cyclized peptide was reacted with 5-carboxyfluorescein $N$-succinimidyl ester (2 equiv; Tokyo Chemical Industry Co., Ltd., Japan) and $N$-methylmorpholine (1 equiv), and purified by RP-HPLC to provide peptide 4. MS (MALDI-TOF) Calcd for $\mathrm{C}_{123} \mathrm{H}_{164} \mathrm{~N}_{24} \mathrm{O}_{37} \mathrm{~S}_{3}[\mathrm{M}+\mathrm{Na}]^{+}: 2688.07$ Found : 2687.92 .

Peptide 5. The linear peptide consisting of the sequence of peptide $\mathbf{5}$ (GSCELLTFLGYPVYCGGGSHHHHHH) was synthesized by the identical procedure described for the general procedure and purified by RP-HPLC. By the identical procedure described for the synthesis of peptide 1 , the cyclization was performed, and the peptide was purified by RP-HPLC to provide peptide 5. MS (MALDI-TOF) Calcd for $\mathrm{C}_{128} \mathrm{H}_{177} \mathrm{~N}_{41} \mathrm{O}_{33} \mathrm{~S}_{2}[\mathrm{M}+\mathrm{H}]^{+}: 2881.29$ Found: 2881.34

Peptide 6. By the identical procedure described for the synthesis of peptide 1, the fluorescein-labelled linear peptide was synthesized and purified by RP-HPLC to provide peptide 6. MS (MALDI-TOF) Calcd for $\mathrm{C}_{72} \mathrm{H}_{76} \mathrm{~N}_{26} \mathrm{O}_{18}[\mathrm{M}+\mathrm{H}]^{+}: 1593.58$ Found: 1593.55

Peptide 7. The linear peptide consisting of the sequence of peptide 7 (MGSSSSCELLTFLGYPVYCG) was synthesized using the general procedure. The linear peptide containing a pair of cysteine was cyclized through disulfide bond by Npys oxidation using Npys-OMe-ChemMatrix ${ }^{\circledR}$ resin (5 equiv; Kokusan chemical Co., Ltd., Japan) in $\mathrm{H}_{2} \mathrm{O} / \mathrm{MeCN}(1: 1=\mathrm{v} / \mathrm{v})$ solution overnight. The resin was filtered, and the filtrate was purified by RP-HPLC to provide peptide 7. MS (MALDI-TOF) Calcd for $\mathrm{C}_{93} \mathrm{H}_{139} \mathrm{~N}_{21} \mathrm{O}_{29} \mathrm{~S}_{3}[\mathrm{M}+\mathrm{Na}]^{+}: 2132.91$ Found : 2132.95 
Peptide 8. By the identical procedure described for the synthesis of peptide 7, peptide 8 was synthesized. MS (MALDI-TOF) Calcd for $\mathrm{C}_{97} \mathrm{H}_{139} \mathrm{~N}_{21} \mathrm{O}_{26} \mathrm{~S}_{3}[\mathrm{M}+\mathrm{Na}]^{+}: 2132.93$ Found : 2133.44

Peptide 9. Peptide 9 was synthesized according to the identical procedure described for the synthesis of peptide 7. MS (MALDI-TOF) Calcd for $\mathrm{C}_{99} \mathrm{H}_{140} \mathrm{~N}_{22} \mathrm{O}_{26} \mathrm{~S}{ }_{3}[\mathrm{M}+\mathrm{Na}]^{+}$: 2171.94 Found : 2172.14.

Peptide10. By the identical procedure described for the synthesis of peptide 7, peptide 10 was synthesized. MS (MALDI-TOF) Calcd for $\mathrm{C}_{97} \mathrm{H}_{139} \mathrm{~N}_{21} \mathrm{O}_{27} \mathrm{~S}_{3}[\mathrm{M}+\mathrm{Na}]^{+}: 2148.92$ Found : 2149.12

Peptide 11. By the identical procedure described for the synthesis of peptide 4, acetyl capped linear peptide (Ac-GKGCELLTFLGYPVYCG) was synthesized. The linear peptide containing a pair of cysteine was cyclized through disulfide bond by air oxidation in $0.1 \mathrm{M} \mathrm{NH}_{4} \mathrm{HCO}_{3}$ buffer for $72 \mathrm{~h}$. The cyclized peptide was purified by RP-HPLC to provide peptide 11. MS (MALDI-TOF) Calcd for $\mathrm{C}_{86} \mathrm{H}_{127} \mathrm{~N}_{19} \mathrm{O}_{23} \mathrm{~S}_{2}[\mathrm{M}+\mathrm{H}]^{+}: 1858.88$ Found : 1858.79

Peptide 12. After the synthesis of protected peptides consisting of the sequence of peptide 12 (CELLTFLGYPVYCG), coupling of 2-(2-naphthyl)acetyl chloride (5 equiv) was carried out with $\mathrm{N}$-methylmorpholine (10 equiv) in $\mathrm{CH}_{2} \mathrm{Cl}_{2}$. The resulting protected peptide resin was cleaved, deprotected and collected by the identical procedure described for the general procedure, and the crude linear peptide was cyclized by the identical procedure described for the synthesis of peptide 7. The cyclized peptide was purified by RP-HPLC to provide peptide 12. MS (MALDI-TOF) Calcd for $\mathrm{C}_{86} \mathrm{H}_{115} \mathrm{~N}_{15} \mathrm{O}_{20} \mathrm{~S}_{2}[\mathrm{M}+\mathrm{Na}]^{+}: 1764.78$ Found : 1765.06.

\section{SPR measurement}

SPR biosensing experiments were performed on a Biacore T200 (Cytiva, U.S.A.) using a single-cycle kinetics method, according to Biacore T200 control software. For all maturement, HBS-EP+ (10 mM HEPES, pH 7.4, $150 \mathrm{mM} \mathrm{NaCl}, 3 \mathrm{mM}$ EDTA, 0.05\% surfactant P20) was used as the running buffer. Biotinylated IL-17A was diluted in HBSEP+ and immobilized on a Biotin CAPture chip (Cytiva, U.S.A.) yielding typical levels of approximately 550 RUs. Peptides were injected at 6.1, 18.5, 55.6, 166.7, and $500 \mathrm{nM}$ at 
a flow rate of $30 \mu \mathrm{L} / \mathrm{min}$ for $120 \mathrm{sec}$, and subsequent dissociation was followed for up to 600 sec. Data processing and analysis were performed using Biacore T200 evaluation software (Cytiva, U.S.A.). Obtained sensorgrams were double referenced against the signal of target non-immobilized path as well as that of no peptide control, before global fitting of the concentration series to the heterogeneous ligand binding model.

\section{ELISA assay}

$100 \mu \mathrm{L}$ IL-17RA (IL-17RA_Fc Chimera, from R\&D Systems, U.S.A.) solution $(2 \mu \mathrm{g} / \mathrm{mL}$ in PBS(-)) was added to a well of a ELISA plate (Nunc-Immuno Module plate, C8, obtained from Thermo Fisher Scientific, U.S.A.), and immobilization was performed at $4{ }^{\circ} \mathrm{C}$ for overnight. The wells were washed with PBS-T (PBS containing 0.05\% Tween-20) for three times, and blocked with BSA ( $3 \%$ in PBS, $300 \mu \mathrm{L} /$ well) for 1 hour at room temperature. The wells were washed with PBS-T twice, and $50 \mu \mathrm{L}$ of peptide solution (diluted in series from DMSO stock solution in PBS containing 1\% BSA) and $50 \mu \mathrm{L}$ of biotinylated IL-17A solution (obtained from R\&D Systems, U.S.A., dissolved as 100 $\mathrm{ng} / \mathrm{mL}$ in PBS containing $1 \% \mathrm{BSA}$ ) were added. The plate was shaken at room temperature for 1 hour, before washing with PBS-T for three times. The final concentrations of tested peptides were from ca. $50 \mathrm{nM}$ to $10 \mu \mathrm{M}$. Then, HRP (horseradish peroxidase) conjugated with streptavidin (Calbiochem, U.S.A., $40 \mathrm{ng} / \mathrm{mL}$ in PBS containing $1 \% \mathrm{BSA}, 100 \mu \mathrm{L}$ ) was added to the well, and the plate was shaken at room temperature for 1 hour in dark. The wells were washed with PBS-T for three times, before addition of OPD detection agent (OPD tablet, Wako Pure Chemical, Japan, dissolved in $0.1 \mathrm{M} \mathrm{NaH}_{2} \mathrm{PO}_{4}$ as instructed by the manufacturer with $0.015 \% \mathrm{H}_{2} \mathrm{O}_{2}, 100$ $\mu \mathrm{L}$ ). After incubation at room temperature for a few minutes in dark, absorbance at 490 $\mathrm{nm}$ was measured by a plate reader (Infinite M Plex, TECAN, Switzerland). After background subtraction, inhibition rate was calculated by (Absno peptide - Abspeptide)/ Absno peptide. Samples were prepared and measured in triplicate. 


\section{Supporting Figures}

$\begin{array}{ll}\text { Base (nt) } & \text { Explanation } \\ 14-33 & \text { T7 promoter } \\ 34-36 & \text { 5'cap } \\ 37-107 & \Omega \text { enhancer } \\ 110-114 & \text { kozak } \\ 115-123 & \text { MGC } \\ 124-150 & \text { Random region } \\ 151-162 & \text { GGGS } \\ 163-180 & \text { His6 Tag } \\ 181-189 & \text { GGS } \\ 190-211 & \text { Linker hybridization region }\end{array}$

GATCCCGCGAAATTAATACGACTCACTATAGGGGAAGTATTTTTACAACAATTACCA ACAACAACAACAAACAACAACAACATTACATTTTACATTCTACAACTACAAGCCACC ATGGGCTGTNNKNNKNNKNNKNNKNNKNNKNNKNNKGGGGGAGGCAGCCATCATCAT CATCATCACGGCGGAAGCAGGACGGGGGGCGGCGTGGAAA

Figure S1. DNA sequence of a model library, used for stability test in Figure 1.

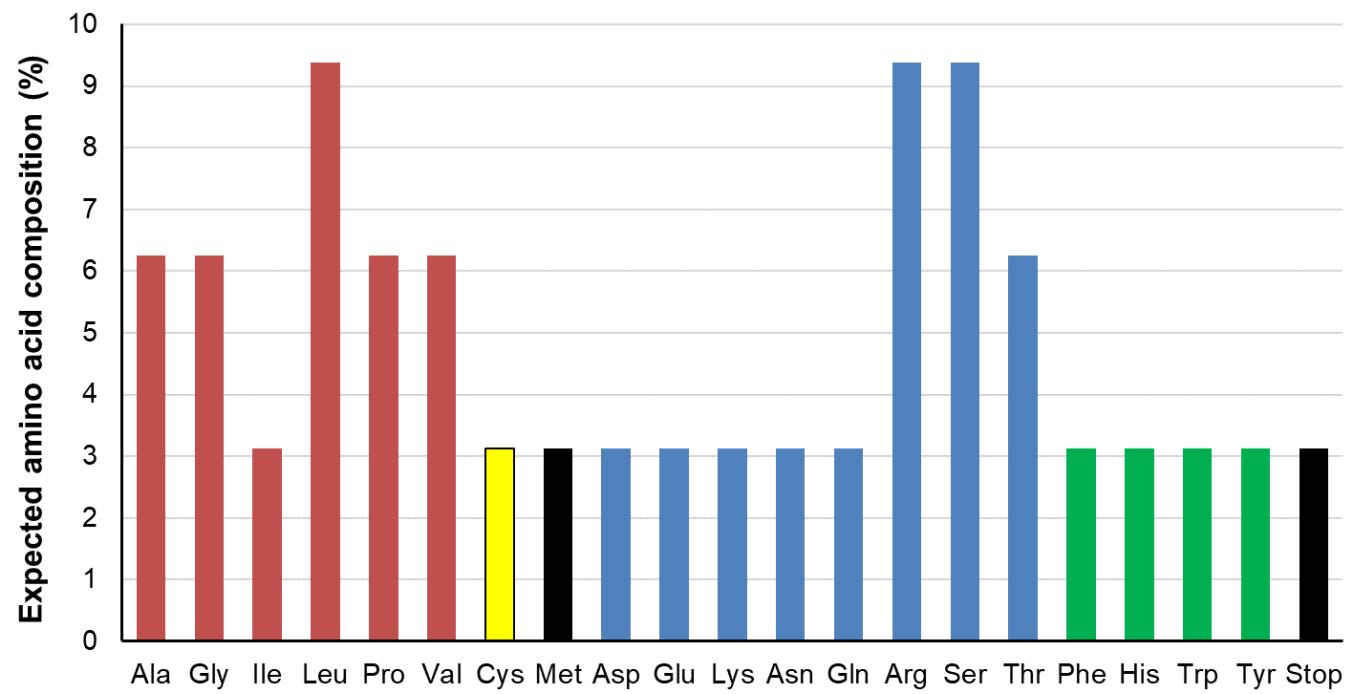

Figure S2. Expected amino acid appearance ratio of NNK codon. 


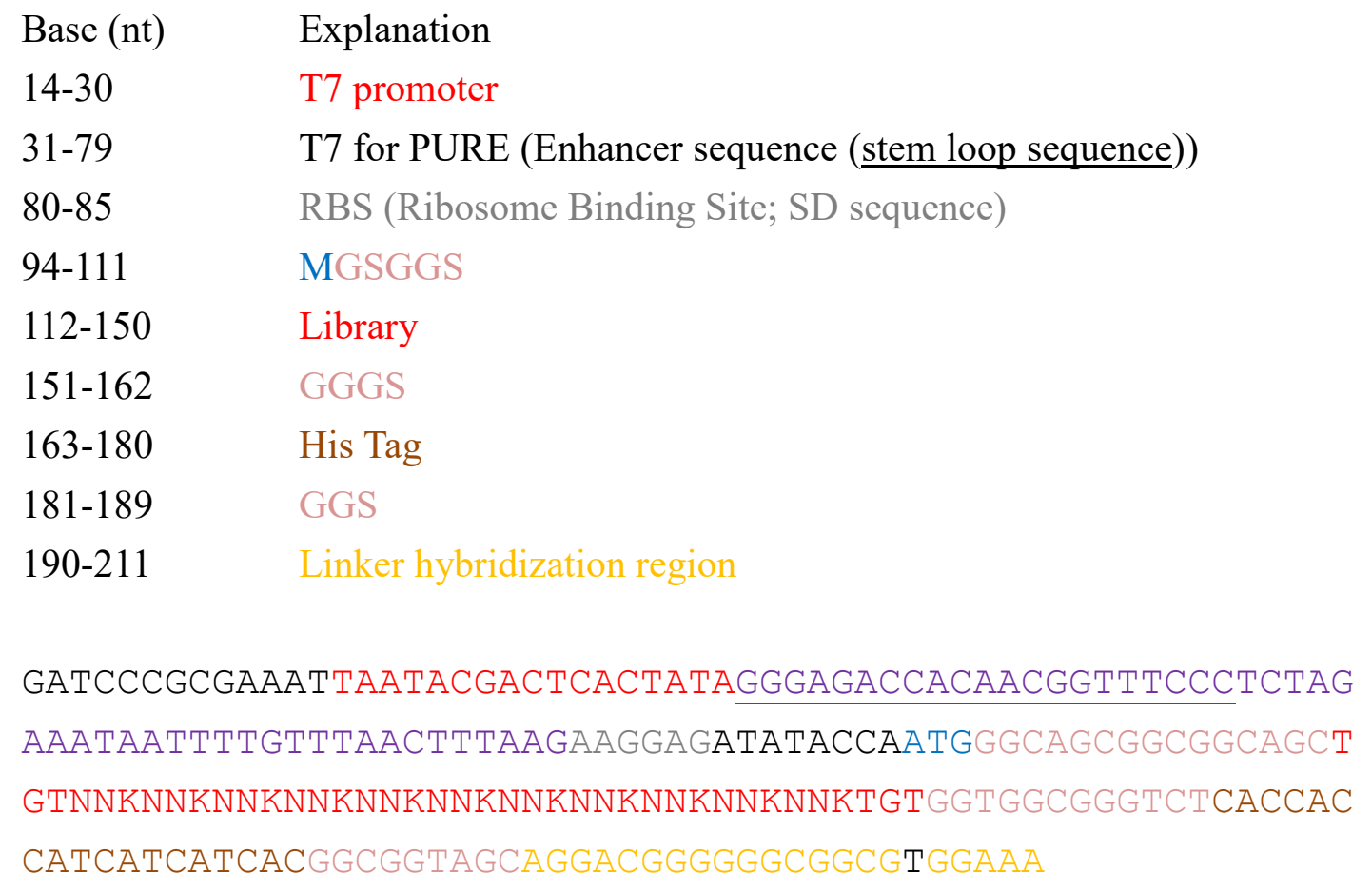

Figure S3. DNA sequence of the C11 library.

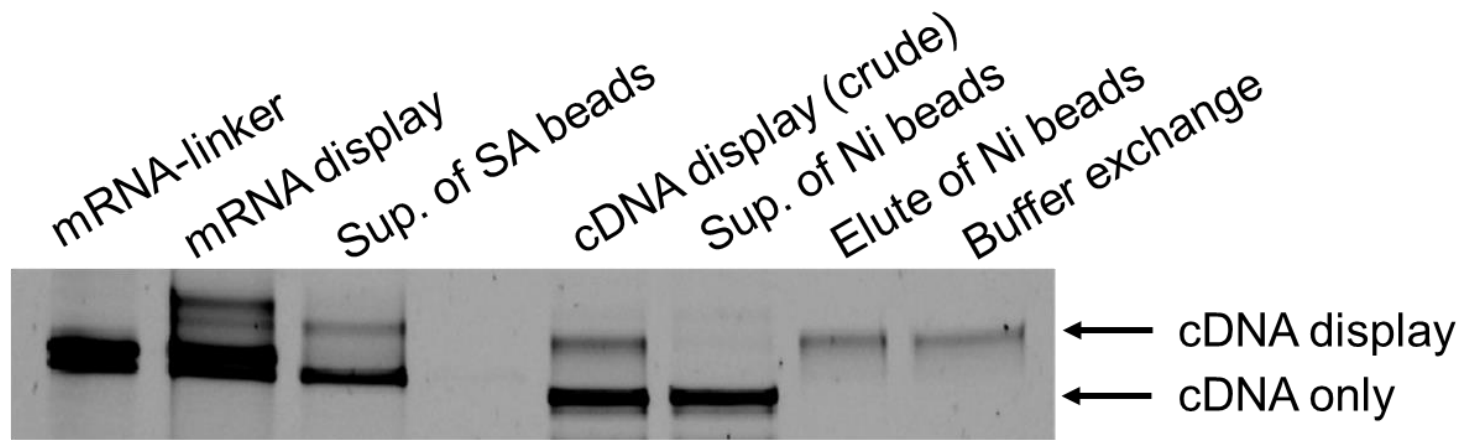

Figure S4. Confirmation of cDNA display formation of C11 library. Samples were run by SDS-PAGE and detected using fluorescence marker attached to the puromycin linker. According to the band intensity, the yield of purified cDNA display molecules was $12 \%$ compared with mRNA-linker. 


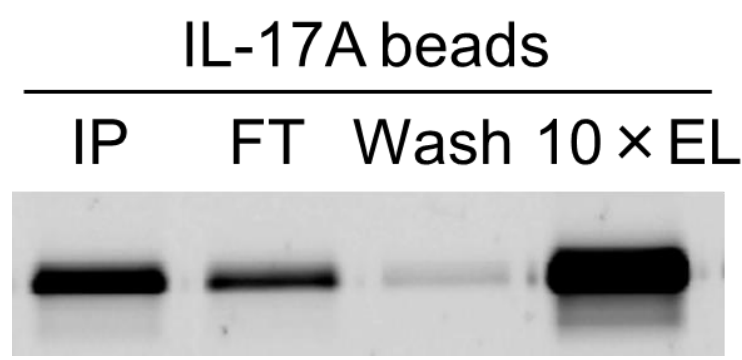

Figure S5. Pull-down and SDS-PAGE analysis of IL17-1-Ser cyclic peptide-linker against IL-17A-immobilized beads in PBS-T. The experiment was like Figure 4B in the main text.

\section{IL17-A beads SA beads

M IP FT Wash EL1 EL2 FT Wash EL1 EL2

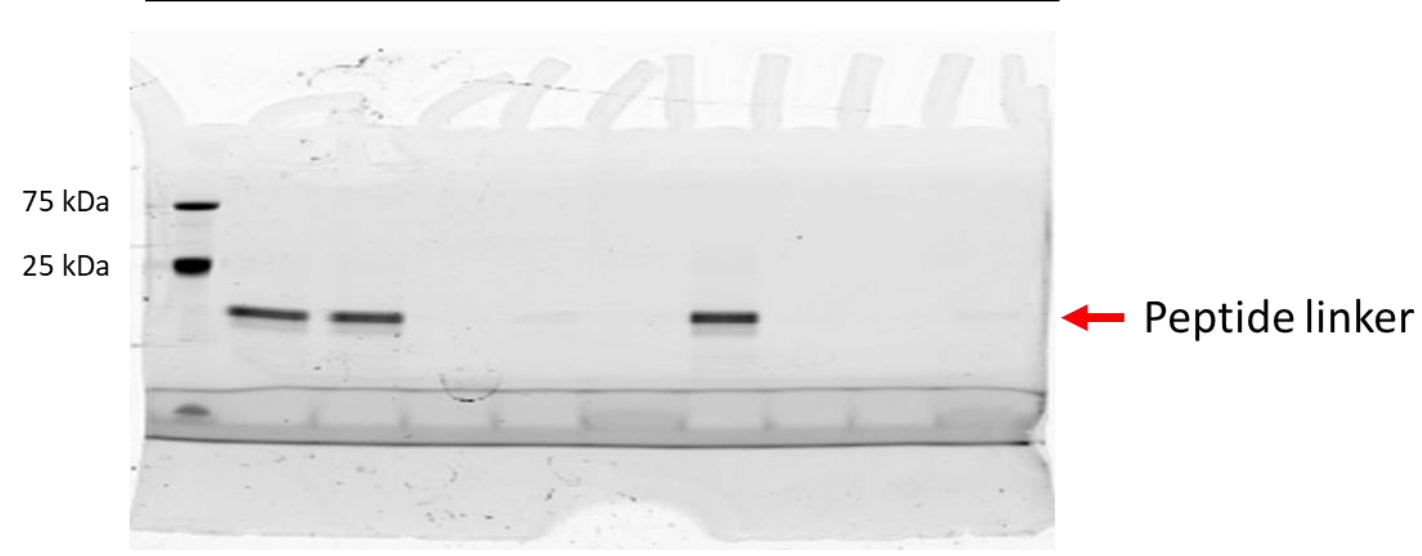

Figure S6. Pull-down experiment of IL17-5 (cyclic peptide) to IL17-A. The protocol was the same as that for Figure 4B. M indicates fluorescent protein size marker, and EL1 and EL2 indicate elution with TCEP and SDS, respectively. PBS-T was used as a buffer for binding. 

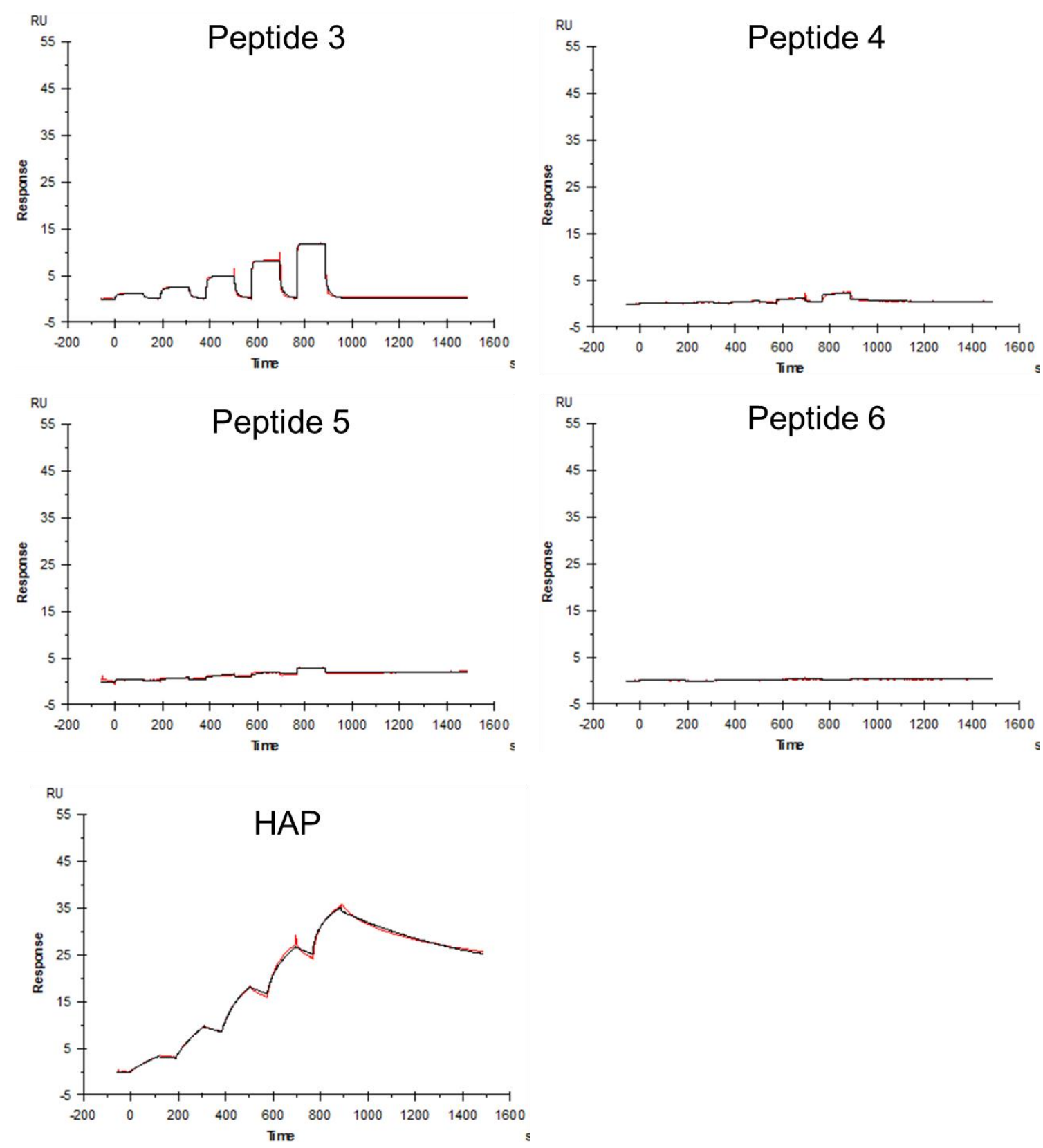

Figure S7. Binding of peptide 3 (top left), 4 (top right), 5 (middle left), 6 (middle right), and HAP (positive control, bottom left) against IL-17A, evaluated by SPR. The binding constant of HAP was $6.2 \mathrm{nM}$, which is approximately the same as the reported value $(2.6 \mathrm{nM})$ in reference $\mathrm{S} 2$. Red lines are experimental data, and black lines are curve-fitted data. 


\section{Supporting Tables}

Table S1. Top read sequences in NGS and their binding affinities to human IL-17A.

\begin{tabular}{|c|c|c|c|c|}
\hline Sample name & Peptide sequence $^{a}$ & Buffer $^{b}$ & Serum $^{b}$ & $K_{\mathrm{D}}[\mathrm{nM}]^{c}$ \\
\hline \multirow[t]{11}{*}{ IL17-1 ${ }^{d}$} & CELLTFLGYPVYC & Yes & Yes & 12.3 \\
\hline & CELMRFLGFYNAC & Yes & Yes & 41.6 \\
\hline & CELAEFLGFNVWC & Yes & Yes & 27.7 \\
\hline & CELLHFLFPDWTC & Yes & Yes & 12.5 \\
\hline & CELLRFLGLVDSC & Yes & Yes & 23.1 \\
\hline & CELWRFLFQDNSC & Yes & Yes & 16.1 \\
\hline & CELMQFLGFEFSC & Yes & Yes & 11.9 \\
\hline & CELLRFLGFRSGC & Yes & Yes & 19.3 \\
\hline & CELANFLGFAIYC & Yes & Yes & 19.1 \\
\hline & CELVKFLFGLRSC & Yes & Yes & 26.0 \\
\hline & CELLLFLGLPVTC & No & Yes & 12.1 \\
\hline \multirow[t]{3}{*}{ IL17-2 } & CELLIYLGVIKVC & Yes & No & 44.1 \\
\hline & CELARFLGFVAPC & Yes & Yes & 48.7 \\
\hline & CELYRFLGLDFTC & Yes & Yes & 31.9 \\
\hline \multirow[t]{4}{*}{ IL17-3 } & CELLRFLGMVEVC & Yes & No & 25.5 \\
\hline & CELLMFLGLTVYC & No & Yes & 43.4 \\
\hline & CELIRFLGFVVNC & Yes & No & 26.1 \\
\hline & CELIMFLGLTGLC & Yes & No & 16.1 \\
\hline IL17-4 & CELVRFLLGPLSC & Yes & No & 39.4 \\
\hline \multirow[t]{2}{*}{ IL17-5 } & CELLTLLGYPVYC & Yes & No & 134 \\
\hline & CELLMFLGLTVYC & Yes & No & 43.4 \\
\hline
\end{tabular}

a For clarity, only the randomized cyclic part is shown.

$b$ "Yes" and "No" indicate whether the sequence was found in the top 100 most frequently read sequences after 5 rounds of selection in buffer and serum.

$c$ The binding affinity of peptide-linker, determined by BLI.

$d$ The sequences described in the main text are highlighted in gray. 
Table S2. Selectivity of IL17-1 to human IL17-A.

\begin{tabular}{ccc}
\hline Peptide & Target & $K_{\mathrm{D}}[\mathrm{nM}]$ \\
\hline${\text { IL } 17-1^{a}}^{a}$ & IL17-A (human) & 12.3 \\
IL17-1a & IL17-A (mouse) & 122 \\
${\text { IL } 17-1^{a}}^{a}$ & IL17-F (human) & N.D. \\
\hline
\end{tabular}

${ }^{a}$ Crosslinked by 1,2-bis(bromomethyl)benzene.

${ }^{b}$ No detectable binding was observed.

Table S3. Effect of crosslinking agents on the affinities of IL17-1 peptide-linkers against human IL17-A. Letters shown in red represent consensus sequence.

\begin{tabular}{ccc}
\hline Crosslinker & Peptide sequence & $K_{\mathrm{D}}[\mathrm{nM}]$ \\
\hline DBX $^{a}$ & CELLTFLGYPVYC & 12.3 \\
BMOE $^{b}$ & CELLTFLGYPVYC & 1.7 \\
DMSO (disulfide) & CELLTFLGYPVYC & 4.4 \\
IL17-1-Ser & SELLTFLGYPVYS & $1.0^{c}$ \\
IL17-1(Bzl) & C (Bzl) ELLTFLGYPVYC (Bzl) & 13.0 \\
\hline
\end{tabular}

\footnotetext{
a 1,2-bis(bromomethyl)benzene

${ }^{b}$ Bis-maleimidoethane

${ }^{c}$ The curve fitting was not very good, so the reliability was poor.
} 
Table S4. Sequences and functions of other synthesized peptides. Pink letters show introduced aromatic residues.

\begin{tabular}{r|r|r|l|c|c}
\hline Sample & N-terminal & \multicolumn{1}{|c|}{ Cyclic body } & C-terminal & $\begin{array}{c}\text { Binding } \\
\text { activity }\end{array}$ & $\begin{array}{c}\text { Inhibitory } \\
\text { activity }\end{array}$ \\
\hline Peptide 7 & MGSSSS & CELLTFLGYPVYC & $G$ & N.D. & N.D. \\
Peptide 8 & MGSGG & CELLTFLGYPVYC & $G$ & N.D. & N.D. \\
Peptide 9 & MGSGG & CELLTFLGYPVYC & $G$ & N.D. & N.D. \\
Peptide 10 & MGSGGY & CELLTFLGYPVYC & $G$ & N.D. & N.D. \\
Peptide 11 & AC-GKG & CELLTFLGYPVYC & $G$ & N.D. & N.D. \\
Peptide 12 & NaIb & CELLTFLGYPVYC & G & N.D. & N.D. \\
\hline
\end{tabular}

a N.D. means no binding and inhibition was detected up to 1 and $10 \mu \mathrm{M}$, respectively. Binding activity was measured by SPR, and inhibitory activity was detected by ELISA. ${ }^{b} \mathrm{Nal}$ stands for 2-(2-Naphthyl)acethyl functional group. 
Table S5. Primers used in this study.

\begin{tabular}{|c|c|}
\hline Name & Sequence (5' to 3') \\
\hline Newleft & GATCCCGCGAAATTAATACGACTCACTATAGGG \\
\hline cnvK-NewYtag & TTTCCACGCCGCCCCCCGTCCT \\
\hline T7PURE & $\begin{array}{l}\text { GATCCCGCGAAATTAATACGACTCACTATAGGGAGACCACAACGGTTTC } \\
\text { CCTCTAGAAATAATTTTGTTTAACTTTAAGAAGGAGATATACCAATG }\end{array}$ \\
\hline T7PUREnew & $\begin{array}{l}\text { GATCCCGCGAAATTAATACGACTCACTATAGGGAGACCACAACGGTTTC } \\
\text { CCTCTAG }\end{array}$ \\
\hline C11Random & $\begin{array}{l}\text { CTTTAAGAAGGAGATATACCAATGGGCAGCGGCGGCAGCTGTNNKNNK } \\
\text { NNKNNKNNKNNKNNKNNKNNKNNKNNKTGTGGTGGCGGGTCTCACCA } \\
\text { CC }\end{array}$ \\
\hline $\begin{array}{l}\text { His } \quad \text { cnvK } \\
\text { NewYtag }\end{array}$ & $\begin{array}{l}\text { TTTCCACGCCGCCCCCCGTCCTGCTACCGCCGTGATGATGATGGTGGTG } \\
\text { AGACCCGCCAC }\end{array}$ \\
\hline $\mathrm{C} 11 \mathrm{qPCR}(+)$ & CGGTTTCCCTCTAGAAATAATTTTGT \\
\hline C11qPCR(-) & GCTACCGCCGTGATGATGA \\
\hline IL17-1 & $\begin{array}{l}\text { GGTGGTGAGACCCGCCACCACAATAAACAGGATAACCCAGAAACGTAA } \\
\text { GCAACTCACAGCTGCCGCCGCTGCCCATTGGTATATCTCCTTCTTAAAG }\end{array}$ \\
\hline IL17-2 & $\begin{array}{l}\text { GGTGGTGAGACCCGCCACCACAAACCTTAATAACACCCAGATAAATCAA } \\
\text { CAACTCACAGCTGCCGCCGCTGCCCATTGGTATATCTCCTTCTTAAAG }\end{array}$ \\
\hline IL17-3 & $\begin{array}{l}\text { GGTGGTGAGACCCGCCACCACAAACCTCCACCATACCCAGAAACCTCA } \\
\text { ACAACTCACAGCTGCCGCCGCTGCCCATTGGTATATCTCCTTCTTAAAG }\end{array}$ \\
\hline IL17-4 & $\begin{array}{l}\text { GGTGGTGAGACCCGCCACCACACGACAGCGGACCCAAAAGAAAACGC } \\
\text { ACAAGCTCACAGCTGCCGCCGCTGCCCATTGGTATATCTCCTTCTTAAAG }\end{array}$ \\
\hline IL17-5 & $\begin{array}{l}\text { GGTGGTGAGACCCGCCACCACAATAAACAGGATAACCCAGAAGCGTAA } \\
\text { GCAACTCACAGCTGCCGCCGCTGCCCATTGGTATATCTCCTTCTTAAAG }\end{array}$ \\
\hline IL17-1E2A & $\begin{array}{l}\text { GGTGGTGAGACCCGCCACCACAATAAACAGGATAACCCAGAAACGTAA } \\
\text { GCAAAGCACAGCTGCCGCCGCTGCCCATTGGTATATCTCCTTCTTAAAG }\end{array}$ \\
\hline IL17-1L3A & $\begin{array}{l}\text { GGTGGTGAGACCCGCCACCACAATAAACAGGATAACCCAGAAACGTAA } \\
\text { GAGCCTCACAGCTGCCGCCGCTGCCCATTGGTATATCTCCTTCTTAAAG }\end{array}$ \\
\hline IL17-1F6A & $\begin{array}{l}\text { GGTGGTGAGACCCGCCACCACAATAAACAGGATAACCCAGAGCCGTAA } \\
\text { GCAACTCACAGCTGCCGCCGCTGCCCATTGGTATATCTCCTTCTTAAAG }\end{array}$ \\
\hline IL17-1L7A & $\begin{array}{l}\text { GGTGGTGAGACCCGCCACCACAATAAACAGGATAACCAGCAAACGTAA } \\
\text { GCAACTCACAGCTGCCGCCGCTGCCCATTGGTATATCTCCTTCTTAAAG }\end{array}$ \\
\hline IL17-1G8A & $\begin{array}{l}\text { GGTGGTGAGACCCGCCACCACAATAAACAGGATAAGCCAGAAACGTAA } \\
\text { GCAACTCACAGCTGCCGCCGCTGCCCATTGGTATATCTCCTTCTTAAAG }\end{array}$ \\
\hline
\end{tabular}




\section{Supporting References}

S1. Terai, T., Anzai, H., Nemoto, N. Selection of Peptides that Associate with DyeConjugated Solid Surfaces in a pH-Dependent Manner Using cDNA Display. ACS Omega 2019, 4, 7378-7384.

S2. Liu, S., Desharnais, J., Sahasrabudhe, P. V., Jin, P., Li, W., Oates, B. D., Shanker, S., Banker, M. E., Chrunyk, B. A., Song, X., Feng, X., Griffor, M., Jimenez, J., Chen, G., Tumelty, D., Bhat, A., Bradshaw, C. W., Woodnutt, G., Lappe, R. W., Thorarensen, A., Qiu, X., Withka, J. M., Wood, L. D. Inhibiting complex IL-17A and IL-17RA interactions with a linear peptide. Sci. Rep. 2016, 6, 26071. 